\title{
Application of Sustainable Road Drainage System: Simulation by Using SWMM Program
}

\author{
Andung Yunianta*, Suripin, Bagus Hario Setiadji \\ Department of Civil Engineering, Diponegoro University, Indonesia
}

Received November 28 2019; Revised January 16, 2020; Accepted Febuary 7,2020

\begin{abstract}
Copyright $@ 2020$ by authors, all rights reserved. Authors agree that this article remains permanently open access under the terms of the Creative Commons Attribution License 4.0 International License
\end{abstract}

\begin{abstract}
High levels of rainfall are generally followed by increased volume of surface runoff and the potential for standing water. Stagnant water on the roads has a negative impact on road users and road damage. The concept of sustainable road drainage has the potential to be developed in dealing with the quantity of runoff water. This study aims to evaluate the existing road drainage system and implement a sustainable road drainage system. The location chosen as the object of research is Diponegoro University Campus area, Tembalang District, Semarang City. Use of the SWMM program which contains a set of flexible hydraulic modeling capabilities used to direct runoff and external inflows through a network of pipe drainage systems, channels, storage units and diversion structures.From the results of the hydrograph analysis, the largest discharge was found in the Outfall of the Center for Environmental Research with a discharge of $5.7 \mathrm{~m}^{3} /$ sec and the lowest discharge at the outfall of the Faculty of Business Economics with a discharge of $0.07 \mathrm{~m}^{3} / \mathrm{sec}$. Whereas the longest flood time that occurred was at the Outfall of the Faculty of Business Economics with a time of 4 hours 45 minutes and the shortest flooding time was at the Jurang Belimbing Outfall with 1 hour and 15 minutes. The sustainable road drainage system model applied is a road drainage channel with the addition of fine and coarse aggregate filters to the channel and integrated with infiltration wells. Thus, the drainage channel is able to reduce surface water flow to other areas and improve water quality.
\end{abstract}

Keywords Sustainable Roads Drainage, Simulation, SWMM

\section{Introduction}

In quantity, rainfall that falls on the surface of the roads and its surroundings will burden the drainage system.
Stagnant water that occurs during the rainy season in Indonesia can become a flood if not anticipated and managed properly. This incident occurs in almost all cities in Indonesia and recurs every year, but this problem has not been resolved, it even tends to increase, both frequency, breadth, depth and duration. Therefore every development of the city must be followed by an evaluation and improvement of the overall drainage system, not only at the development site, but also the surrounding area affected (Rudiono, 2018). Serious problems, especially in the rainy season where there is a pool of water, so that it can have a negative impact on the surrounding community and the condition of the road itself such as damage to roads and interrupted traffic flow (Hendratta, 2014). Drainage facilities are provided to ensure timely runoff of surface water generated from large impermeable surfaces. Good drainage is also supported by surface slopes that have adequate slope (Owuama, 2014). Surface water runoff in cities has a negative impact on receiver flow and various solutions have been proposed to limit the effects of urbanization on water balance. This solution suggests managing urban runoff and reducing sources of pollutants (Rizzo et al., 2018).

Our observations on the campus environment of Diponegoro University revealed that the existing drainage system still uses the concept of conventional drainage, which is made of waterproof channels, causing disruption to the hydrological cycle. Surface water flow increases, groundwater replenishment decreases and the level of water quality also decreases. Surface water runoff increases, groundwater replenishment decreases and water quality levels also decrease. Water is very important for urban development, although urban flooding greatly affects city life. Urban spatial planning sets new patterns for natural drainage systems and changes the hydrological cycle, increasing peak discharge. The urban drainage system is designed to deal with sanitation problems and suffice the system for higher runoff. Traditional flood control projects tend to focus on increasing disposal 
capacity. The concept of sustainability in urban drainage, states that urban flooding is not only transferred, but is absorbed into the ground (infiltration) and the drainage system must be planned together with urban development (Miguez, Bahiense, Rezende, \& Veról, 2012). Therefore it is necessary to develop an environmentally friendly road drainage system, which is a drainage system that is able to control surface runoff and maintain runoff water quality conditions. Sustainable Urban Drainage Systems (SUDS) is a system consisting of one or more structures that are built to manage surface runoff. Sustainable drainage systems have gained increasing public interest in recent years, as a result of their positive effects on water quality and quantity problems and additional recreational facilities felt in the urban landscape (Zhou, 2014).

The sustainable drainage system aims to reduce problems caused by surface runoff, it also aims to reduce the problem of water pollution (aquatic) and increase the value of water use, especially in urban environments. Drainage ecology to support sustainable drainage systems in urban areas, especially in developing countries (Parkinson \& Mark, 2005). The use of infiltration practices as a basis for developing sustainable urban drainage systems is limited to excessive pollution in runoff water, especially from roads, due to land availability. (Mrowiec, 2016). Sustainable drainage systems (SuDS) have become a promising solution to improve watertight by reducing the volume of water flow and flow rates, and improving water quality (Kanso et al., 2018).

The concept of an environmentally friendly or sustainable road drainage system where surface water runoff is infiltrated through an integrated artificial facility consisting of side channels, filter layers and infiltration wells (Yunianta, Suripin, \& Setiadji, 2018). So a sustainable urban drainage system (SUDS) was developed to model a drainage system that absorbs runoff water to the ground or is often referred to as infiltration. This infiltration system forwards runoff water into drainage channels and is processed with filters to filter out pollutants or wastes involved in runoff water. Filtration systems use geotextiles or other media as pollutants or waste filters (Golio, 2001). Drain / Infiltration Trenches Filter Drains / Infiltration Trench uses a drainage system on the right and left side of the road as a permeable media that can drain runoff water on the road and carry out temporary water treatment before the water is drained to the ground. The results showed that the concept of sustainable road drainage has the potential to be developed in handling the quantity of runoff water. The relationship between rainfall, runoff volume, area ratio, dimensions of drainage channels, aggregate filters on the channel and integrated into infiltration wells, was developed to realize a sustainable road drainage model (Yunianta, Suripin, \& Setiadji, 2019). The total efficiency of runoff reduction in infiltration trenches can be used as a main indicator of rainfall performance management. Analytic equations were derived to estimate the rate of runoff reduction in infiltration trenches. Equations taken as input variables are the area coverage, storage space provided by the trench reservoir, the rate of ground water infiltration through the bottom of the soil trench, and parameters representing local climatic conditions (Guo \& Guo, 2018).

Low-impact development (LID) enables greater development potential with less environmental impact using flood water control distributed at locations that achieve a good balance between conservation, growth, ecosystem protection, and public safety (J. C. Y. Guo, 2009). The growth of cities must be carefully planned, to deal with relevant hydrological changes, which are caused by the effects of urbanization. Often, the increase in surface areas that are waterproof is a major cause of urban flooding. For this reason, the concept of a new urban drainage design has been investigated in recent decades, seeking a more sustainable storm water management approach. The concept of sustainability in urban drainage implies that flooding may not be transferred downstream. Storage and infiltration measures, distributed in watersheds and integrated with urban landscapes, must be introduced to reduce flood peaks and rearrange flood flow patterns (Miguez, Bahiense, Rezende, \& Veról, 2014).

SWMM software program provides convenience in determining flood discharge and determining the location of drainage disposal outlets in an area, and will make it easier to design drainage channels. SWMM is part of a continuous effort study to model the anticipated performance of flood management practices and models that can calculate the percentage reduction in runoff volume, reduction of peak runoff discharge, runoff hydrograph time, and potential runoff reduction due to infiltration. (Abi Aad, Suidan, \& Shuster, 2010). SWMM provides environmental integration for study area data input, hydrology, water quality simulation, and hydraulics. Besides that it is also a flexible hydraulic model that is used to direct runoff water and inflow through a network of drainage pipes, channels, storage units, and diversion structures (Rossman, 2010). Studies that apply the SWMM model to flood management adjacent to a road. Runoff water basin infiltration are instrumented at both inlet and outlet locations. This model is used to simulate flood performance in hydrographs and pollutants during different flood events (Wang, Forman, \& Davis, 2018). SWMM is used to design a drainage system that efficiently handles flooding with a 10-year payback period design with the provision of a multi-use containment pool. This multipurpose containment pool helps reduce the peak flow of hydrograph that comes out downstream and also functions as a rain structure. Observations were made on a large number of drainage problems that could be resolved by providing proper connectivity in the runoff water channel and keeping it clean during the rainy season (Bisht et al., 2016).

Road drainage canals in the Dipoengoro University 
Campus in Semarang, Tembalang District, Semarang City, still use channels with open channel types that are on the right and left of the road. The drainage system still drains surface water to be moved to other lower places or other receiving water bodies such as rivers. This condition is still moving water from one location to another so that it burdens the quantity of water in another place which can certainly create problems in other areas. For this reason, a drainage system is needed that is more environmentally friendly and can improve water use in the campus area. Typical conditions of roads and drainage channels in the Dipoengoro University Campus in Semarang are shown in Figure 1.

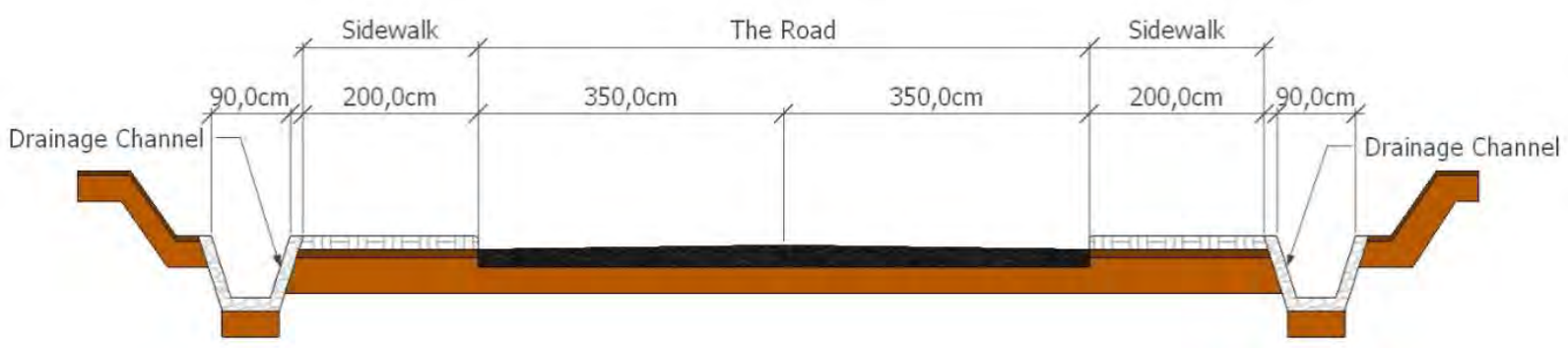

Figure 1. Typical Existing Condition of the Jalan Drainage Canal in the Tembalang Undip Area

The purpose of this study is to evaluate the existing drainage system, especially drainage that is on the side of the road or road drainage in the campus environment Undip Tembalang, to get an outfall or outlet point and flood discharge that occurs in the drainage system with the SWMM program. Application of sustainable road drainage models, in order to improve water quality with infiltration systems and the use of infiltration wells as reservoirs. The system is to increase the carrying capacity of the environment, land conservation and restore the water cycle. It is worth to note that the use of the term road in this study refers to the regulations that apply in Indonesia. The road according to Indonesian Law No. 38 of 2004 article 1 paragraph (4) is defined as land transportation infrastructure which covers all parts of the road, including complementary buildings and equipment intended for traffic that is on the surface of land and / or water, and above the water surface, except railroad tracks, lorry road, and cable road. In this study the road in question is a road that is in an urban area with flexible pavement or rigid pavement with equipment, including the existence of a road drainage system.

\section{Method}

In general, hydrological analysis is a preliminary analysis part in the design of hydraulic buildings. The understanding contained therein is that the information and quantities obtained in hydrological analysis are important input in subsequent analyzes. Hydrologic phenomena such as the amount of rainfall, temperature, evaporation, sun exposure time, wind speed, river discharge, river water level, flow velocity and river sediment concentration will always change with time. In general, hydrological analysis is a preliminary analysis part in the design of hydraulic buildings. Hydraulic buildings in the field of civil engineering can be in the form of culverts, weirs, overflow buildings, flood retaining embankments, and so on. The location chosen as the object of research is Semarang City especially Diponegoro University Campus Area, Tembalang District. Hydrological analysis is needed to calculate flood discharge at Tembalang UNDIP Campus. The steps to get the discharge plan are as follows:

1. Distribution of Regional Rainfall (Area CA)

To get an idea of the distribution of rain throughout the CA, several stations were chosen that were scattered throughout the CA. Selected stations are stations that are within the watershed area coverage and have complete rain measurement data. Some methods that can be used to determine average rainfall are the Thiessen, Arithmetic and Isohyet Maps. In this hydrological analysis, it uses a rain station reference, Sta Rain Pucanggading.

2. Analysis of Rainfall UNDIP Tembalang Campus Area

Rain calculation for this study location is in the form of annual daily rainfall with a data length of 25 years, from 1994 to 2018. The number of rain stations used is 1 (one) rain station close to CA, namely the Pucanggading rainfall station. From this data, the rainfall data at the Pucanggading Rain Station represents the characteristics of rain in the study area.

3. Rainfall Intensity Analysis

Analysis of rainfall intensity can be processed from rainfall data that has occurred in the past. Analysis of rainfall intensity related to concentration time (tc). 
The formula used to find the concentration time uses the Kirpich equation, as follows:

$$
t_{c}=\left(\frac{0,87 x L^{2}}{1000 x S}\right)^{0,385}
$$

where:

$t_{c} \quad$ : concentration time (hours)

$L \quad$ : length of waterway from the farthest point to the point being observed $(\mathrm{km})$

$\mathrm{S} \quad$ : average slope of the water course

Table 1. Results of Calculation of Concentration Time (tc)

\begin{tabular}{|c|c|c|c|c|c|c|c|}
\hline \multirow{2}{*}{ Basin } & \multicolumn{2}{|c|}{ Length } & \multicolumn{2}{c|}{ Elevation } & \multirow{2}{*}{ Slope } & \multirow{2}{*}{$\begin{array}{c}\text { tc } \\
\text { (Hour) }\end{array}$} & tc (Rounded) \\
\cline { 2 - 8 } & $\mathrm{m}$ & $\mathrm{km}$ & Upstream & Downstream & & & 1.00 \\
\hline UNDIP Campus & 651.47 & 0.65 & 211.50 & 198.00 & 0.0207 & 0.025 & \\
\hline
\end{tabular}

Source: Results of Analysis, 2019

The planned rainfall data is used as a basis for calculating the magnitude of rainfall intensity. This is done by approaching an hourly rain hyetograph diagram. Next is the Hyetograph of Rainy Days CA Campus UNDIP Tembalang.

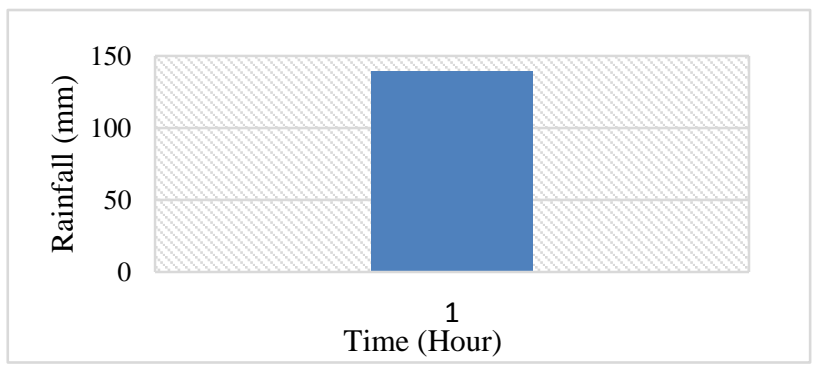

Figure 2. Rainy Hour Hyetograph of CA Tembalang UNDIP Campus

The percentage in the hydrograph is multiplied by the rainfall plan to get the amount of rainfall intensity. The following calculation of rainfall intensity for the return period of 5 years.

Table 2. Results of Rain Intensity Calculation

\begin{tabular}{|c|c|c|}
\hline $\begin{array}{c}\text { Rainfall Plan } \\
\text { (5 th) }\end{array}$ & $\begin{array}{c}\text { Rainfall The Hour } \\
\text { (\%) }\end{array}$ & $\begin{array}{c}\text { Rainfall Intensity } \\
\text { (mm) }\end{array}$ \\
\hline 139 & $100 \%$ & 139 \\
\hline
\end{tabular}

In the design of the road drainage model the formula is used to determine the dimensions of the drainage channel based on the aggregate requirements for the filter, assuming using permeable pavement. Permeable pavement technology is an important aspect in sustainable design. One tool in the design of sustainable infrastructure is the use of permeable pavement systems to help reduce flood water runoff. The ability to use large areas occupied by pavement to improve hydrology and groundwater replenishment has many benefits (Hein, Swan, \& Schaus, 2010).

Permeable sidewalks are one of the most important Low Impact Development (LID) techniques. Usually used to reduce runoff volume, peak flow and pollutant load. Despite the lack of adequate modeling tools is a limiting factor in permeable pavement diffusion. Modeling infiltration phenomena in porous media is very complex because of its highly unsaturated character (Carbone, Brunetti, \& Piro, 2014).

In determining the dimensions of the applied road drainage channel, the calculation of aggregate filter depth is assumed by following the permeable pavement calculation procedure with Equation below (Smith, 2006).

$$
d_{p}=\frac{\Delta Q_{c} R+P-f T}{V_{r}}
$$

where:

$d_{p} \quad=$ Aggregate depth (m)

$\Delta Q_{c} \quad=$ total runoff from coverage area contribution $(\mathrm{m} / \mathrm{hr})$

$R=\left(A_{c} / A_{p}\right)$ the value of the contribution of the coverage area with permeable area 
$\mathrm{P} \quad$ = rainfall design $(\mathrm{m})$

$\mathrm{f} \quad=$ infiltration rate design $(\mathrm{m} / \mathrm{hr})$

$\mathrm{T} \quad=$ effective time of infiltration (hr)

$\mathrm{Vr}=$ void ratio for aggregate

\section{Results}

The Catchment Area reviewed in the calculation is Tembalang UNDIP Campus which is then divided into Subcatchments. The depiction of subcatchment is done by dividing residential areas and roads that are adapted to drainage channels in existing conditions. In addition, the depiction of subcatchment is also determined based on the flow direction and elevation in the existing conditions. Water system and retention ponds Subcatchment in the SWMM model can be seen in Figure 3.

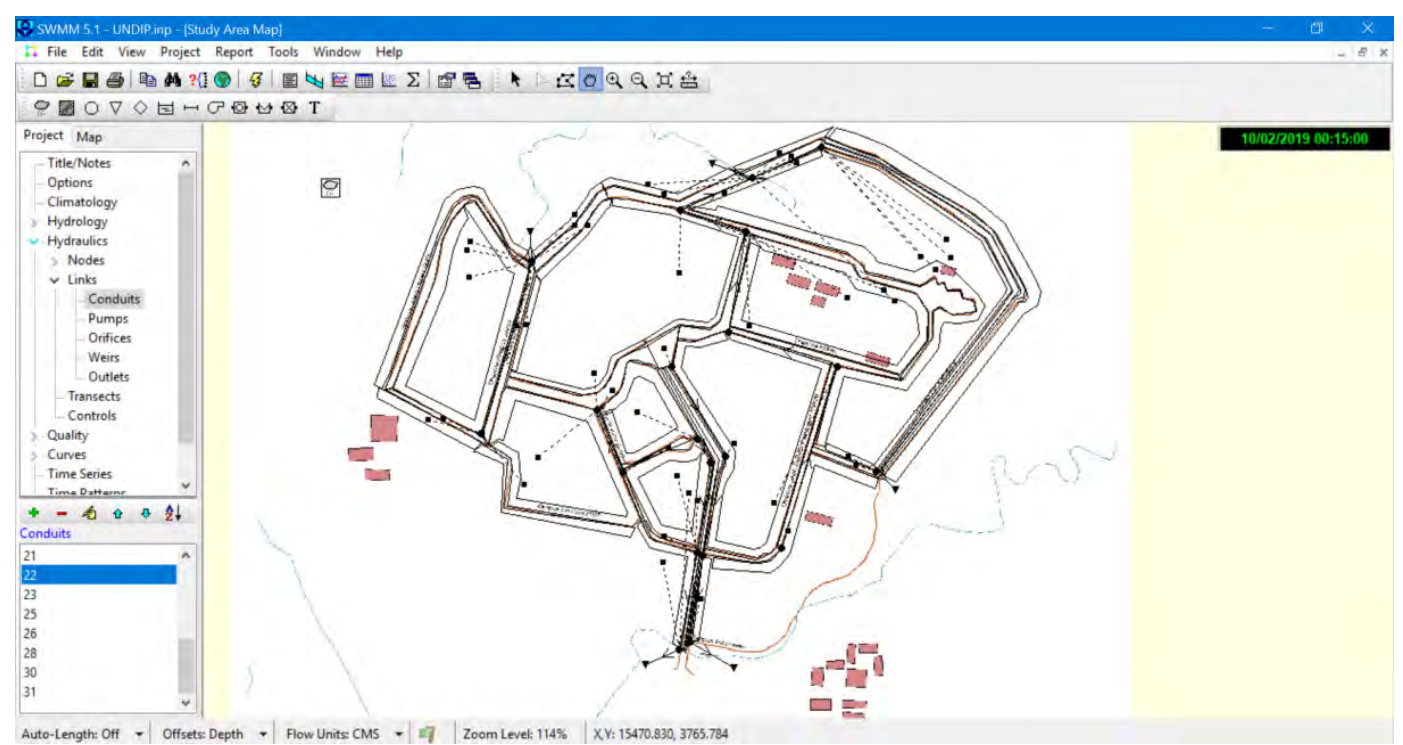

Figure 3. Subcatchment Network in the SWMM Model

Actual conditions in the field indicate that there are several outfalls or discharges on the Tembalang UNDIP Campus as shown in Figure 4.

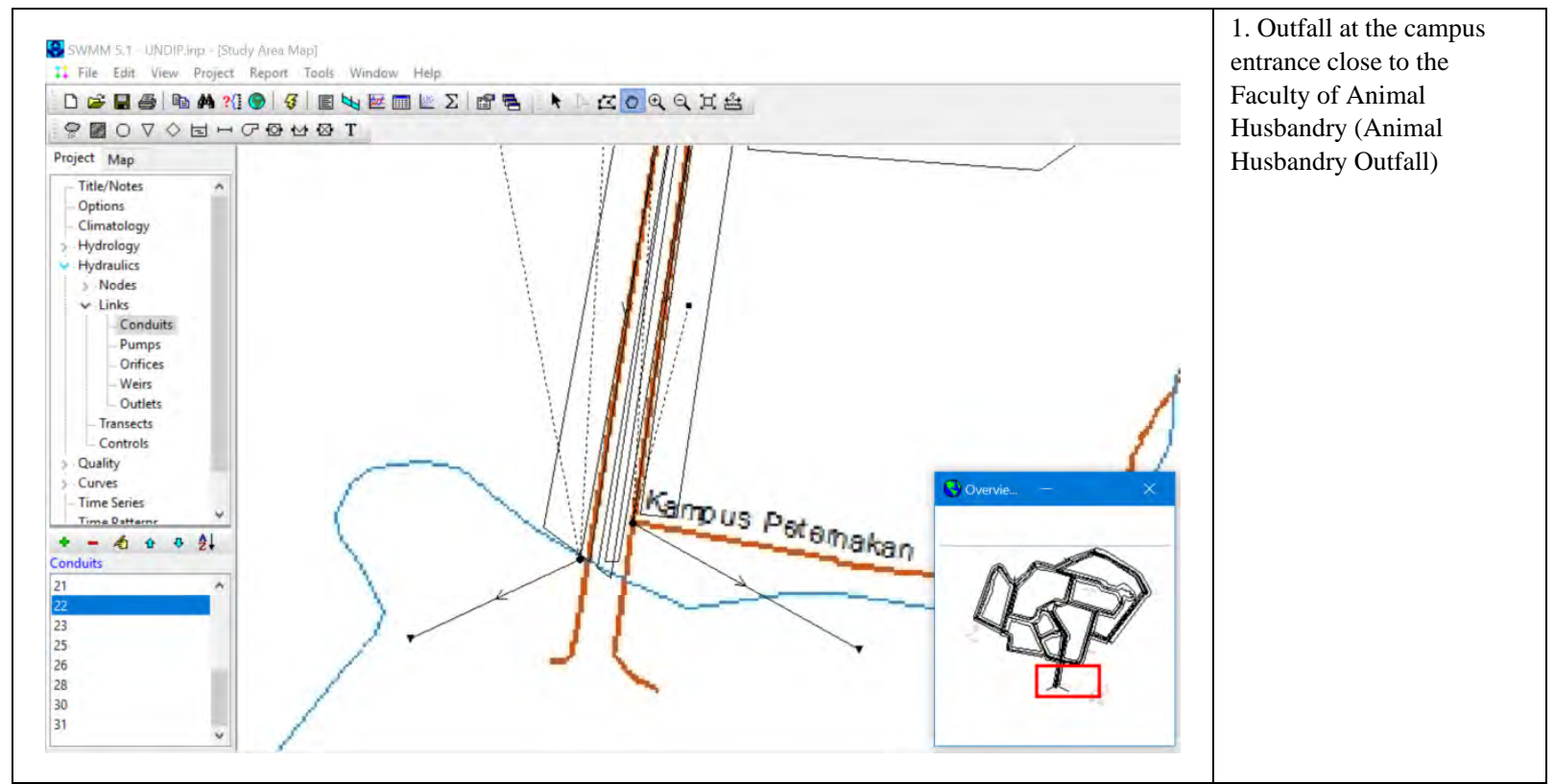




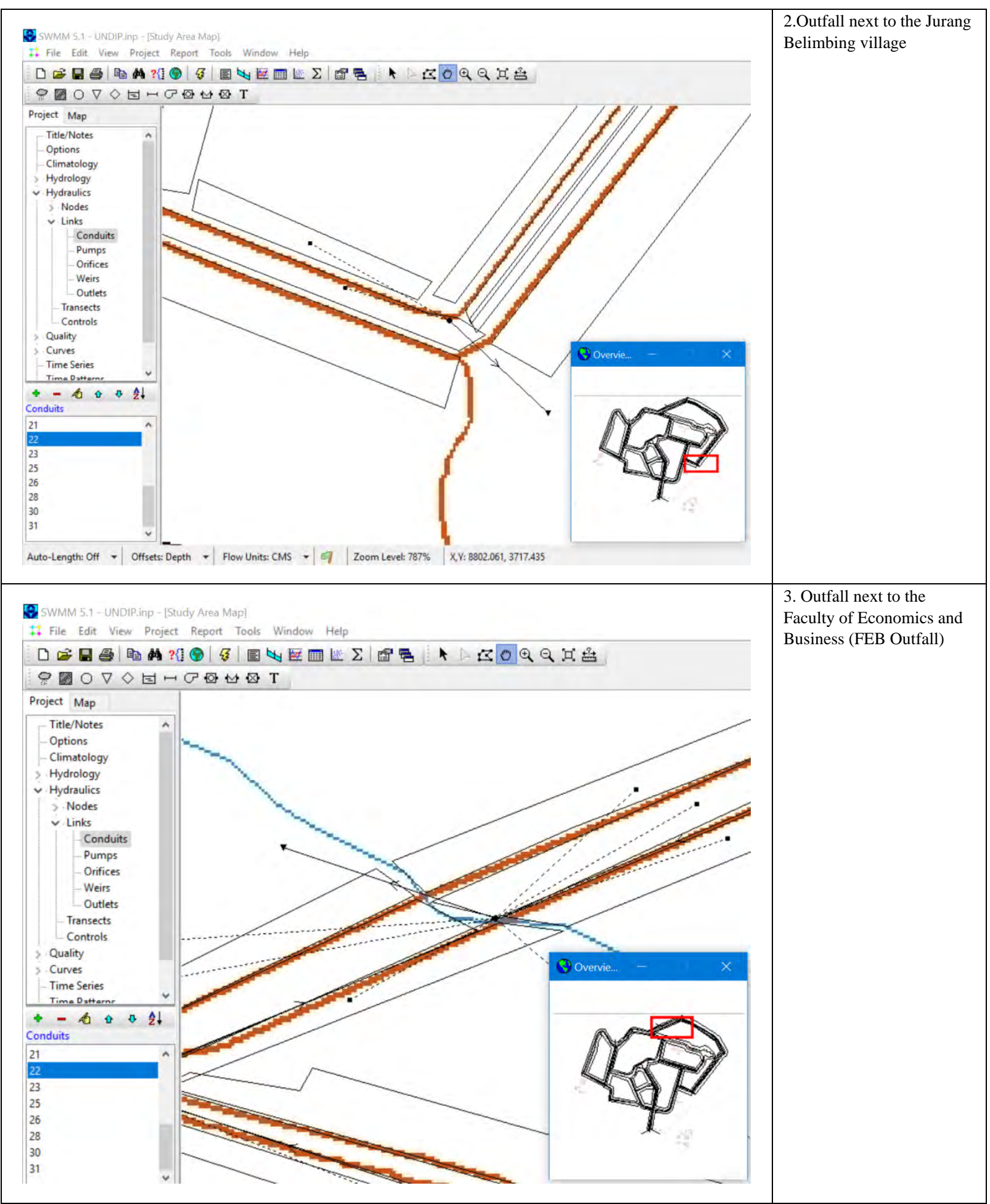


8. SWMM 5.1 - UNDPIP.inp - IStudy Ares Mapi

16. File Edit View Project Report Tools whident Help

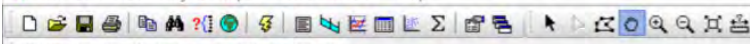

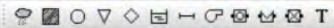

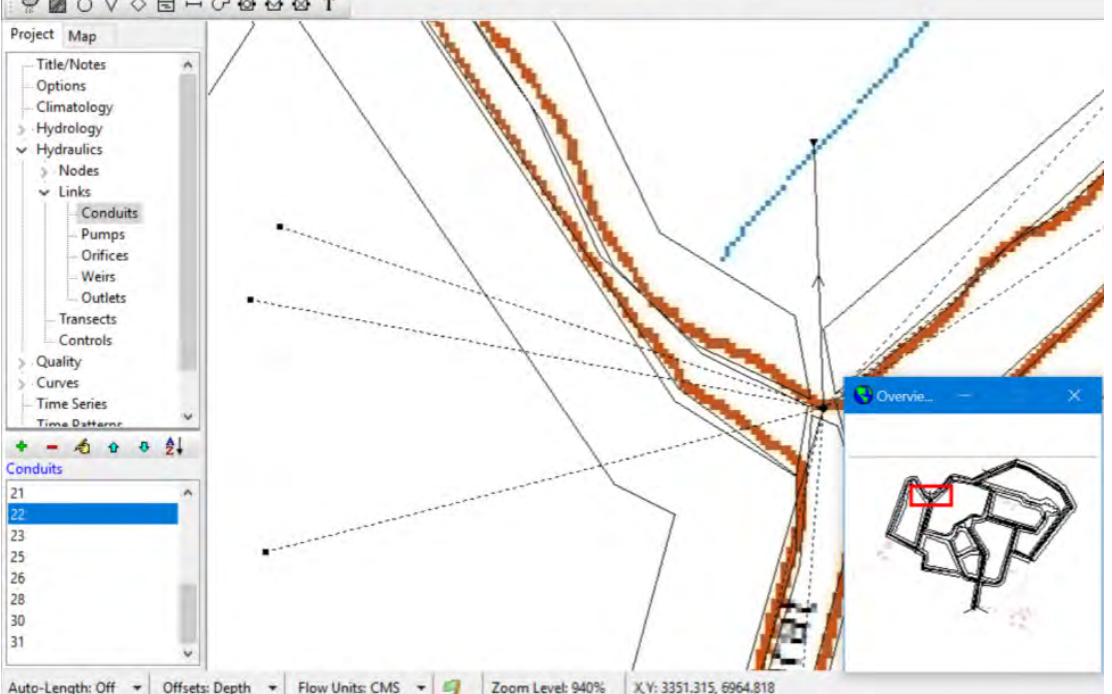

4. Outfall near PPLH Office (PPLH Outfall)

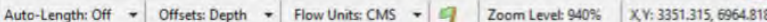

Figure 4. Outfall Points in Tembalang Undip Campus Area

Based on the results of running rainfall-runoff using the SWMM model, the results of the flood hydrograph at each outfall are shown in figures 5 to 9 .

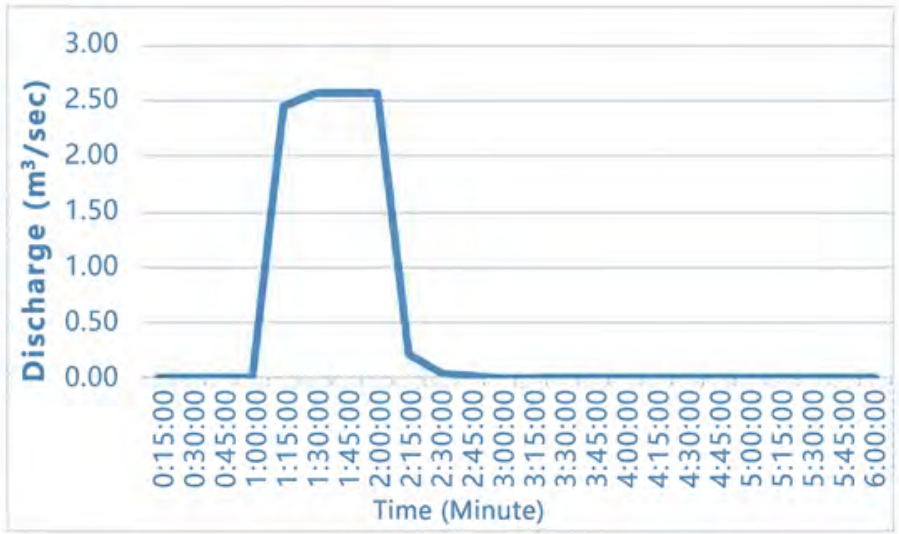

Figure 5. The Left Side Faculty of Animal Husbandry Flood Hydrograph

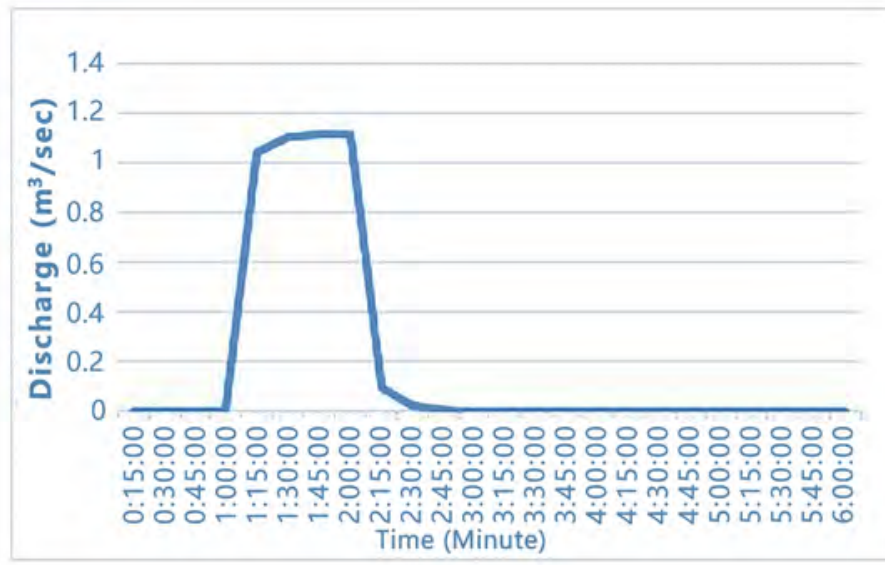

Figure 6. Right Side of the Faculty of Animal Husbandry Flood Hydrograph 


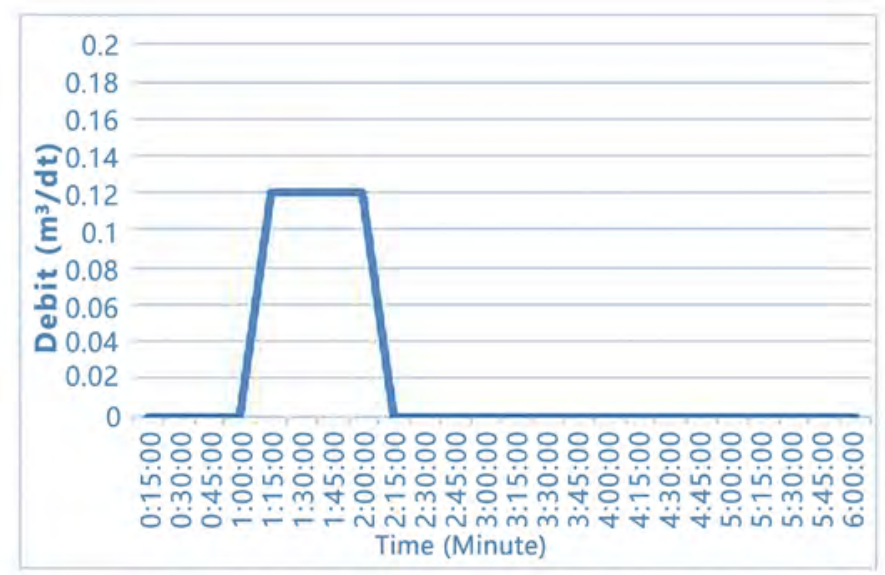

Figure 7. Jurang Belimbing Flood Hydrograph

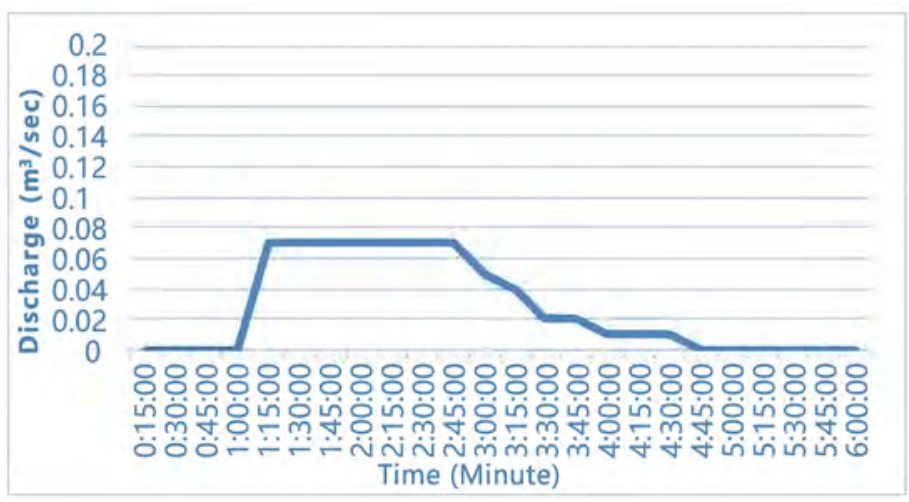

Figure 8. FEB Outfall Flood Hydrograph

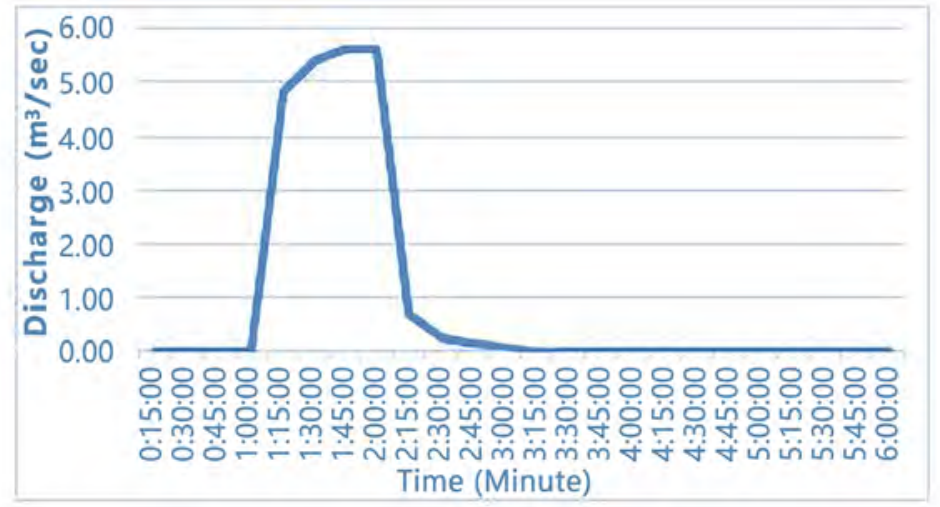

Figure 9. PPLH Outfall Flood Hydrograph

Calculation of the aggregate depth required for the aggregate filter is:

$$
d_{p}=\frac{\left(\frac{1.44}{77.5}\right) \times\left(\frac{77.5}{0.7 x 5}\right)+0.1219168-0.00675}{0.4}=1.3 \mathrm{~m}
$$

So with a width of the upper $70 \mathrm{~cm}$ channel a $130 \mathrm{~cm}$ channel depth will be obtained, for more details calculating the detailed relationship between the width and aggregate depth is presented in Table 3. and Figure 10. 
Table 3. Aggregate Width and Depth Count

\begin{tabular}{|c|c|c|c|c|c|c|c|c|c|c|}
\hline Wide (m) & 0.10 & 0.20 & 0.30 & 0.40 & 0.50 & 0.60 & 0.70 & 0.80 & 0.90 & 1.00 \\
\hline Depth (m) & 7.3 & 3.8 & 2.6 & 2.0 & 1.7 & 1.5 & 1.3 & 1.2 & 1.1 & 1.0 \\
\hline
\end{tabular}

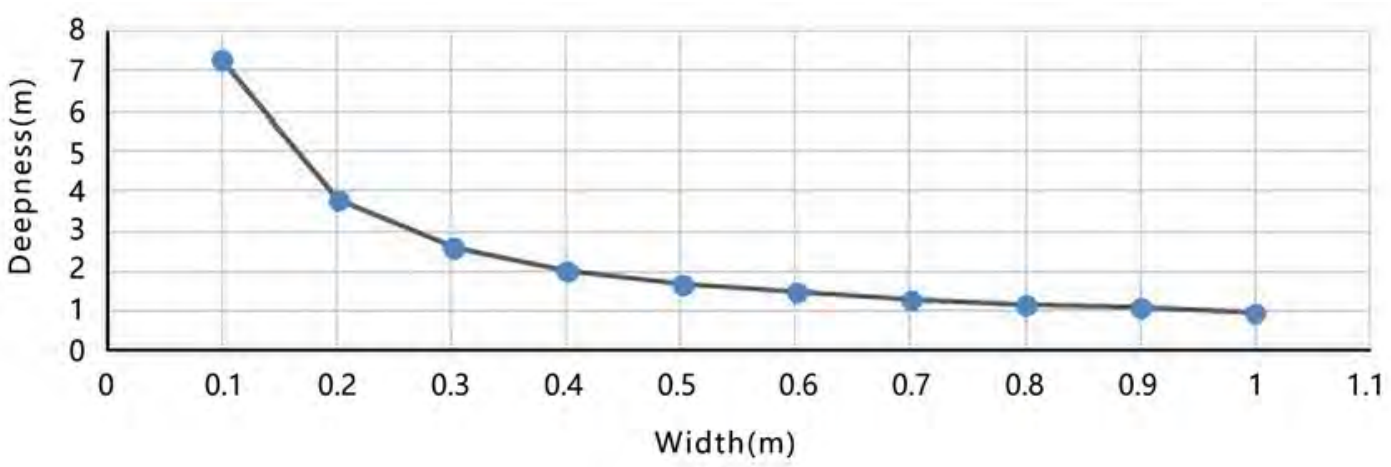

Figure 10. Graph of Aggregate Width and Depth Relationship.

From these results, it was applied to the road drainage channel as in the design of the drainage model with the design of the drainage channel model made of pre-cast concrete quadrilateral (U-ditch) with modifications to the bottom of the channel made water reservoirs. In the drainage channel, fine aggregates and coarse aggregates are placed as filters, and seams are placed between the aggregates. The side of the water reservoir is connected by a pipe to the infiltration well as the final water infiltration into the ground. With this road drainage model, surface water can be absorbed into the ground and not flowed elsewhere. The existence of aggregate filters will also improve the quality of water entering the ground. Details of the road drainage model are shown in Figure 11 and Figure 12.

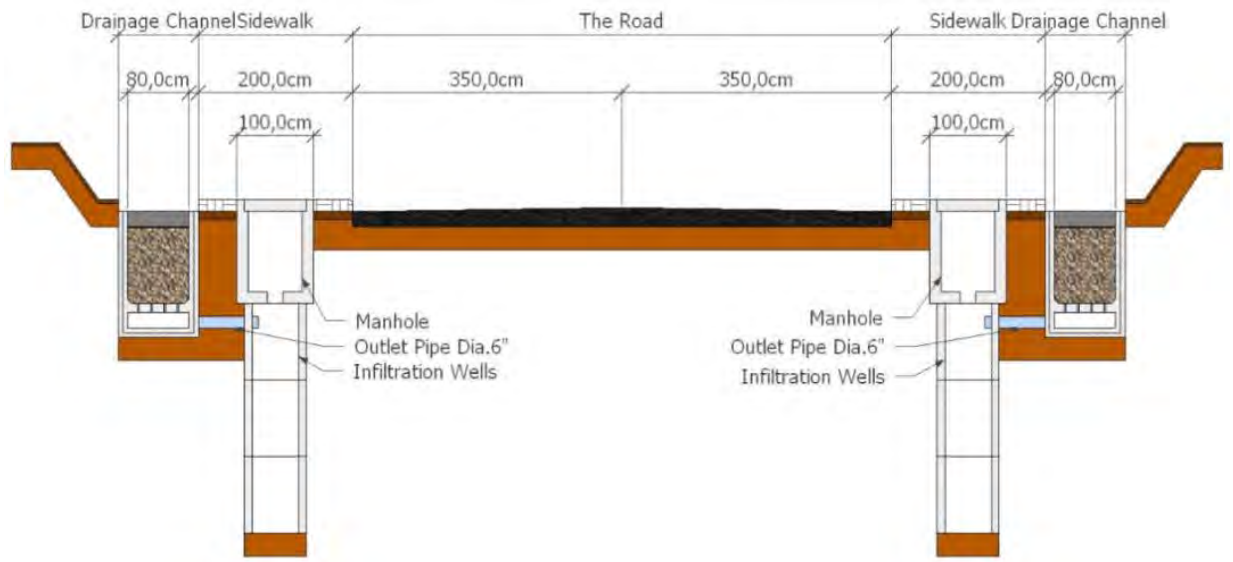

Figure 11. Typical Cross section of the Road

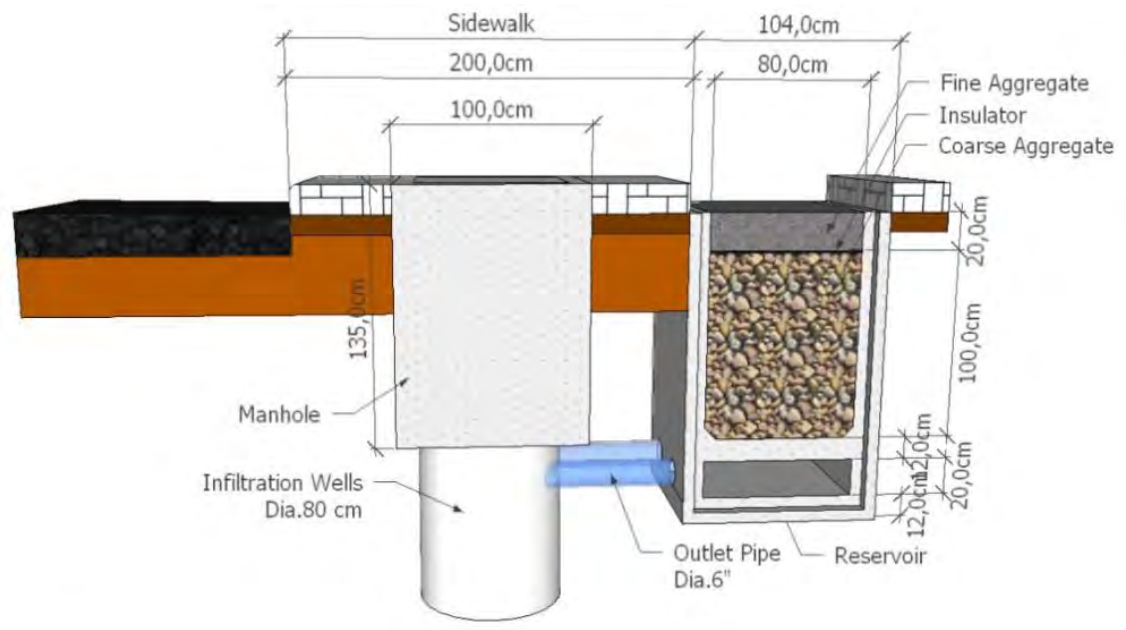

Figure 12. Typical Details of Infiltration Channels and Wells Models 


\section{Conclusions}

The area analyzed includes all drainage on existing roads in the Diponegoro Tembalang University campus area. From the simulation results there are four outfall drainage roads namely; outfall Left Side Animal Husbandry Campus with a debit of $2.51 \mathrm{~m} 3$ / second and time of 1 hour 30 minutes, Outfall Right Side Animal Husbandry with a discharge of $1,1 \mathrm{~m}^{3} /$ second and time of 1 hour 30 minutes, Outfall of the Jurang Belimbing with a debit of $0,12 \mathrm{~m}^{3} /$ second and time of 1 hour 15 minutes, Outfall of the Gap in the Faculty of Business Economics with a debit of 0,007 $\mathrm{m}^{3} / \mathrm{sec}$ and a time of 4 hours 45 minutes and an Outfall of the Environmental Research Center with a discharge of 5,7 $\mathrm{m}^{3} /$ second a time of 2 hours. From the results of the hydrograph analysis, the largest discharge was found in the Outfall of the Center for Environmental Research with a discharge of $5.7 \mathrm{~m} 3$ / sec and the lowest discharge in the outfall of the Faculty of Economics and Business (FEB) with a debit of $0.007 \mathrm{~m} 3$ / sec. The longest flood time that occurred was at the Outfall of the Faculty of Economics and Business (FEB) with a time of 4 hours 45 minutes and the shortest flooding time was at the Jurang Belimbing Outfall with 1 hour and 15 minut

The results of the aggregate depth calculation are used to assume the depth of the drainage channel that is the total depth of the channel $169 \mathrm{~cm}$ and width $104 \mathrm{~cm}$. And the overall aggregate depth is $120 \mathrm{~cm}$ with fine aggregate details of $20 \mathrm{~cm}$ and coarse aggregate of $100 \mathrm{~cm}$ and inter-aggregate sealing is used. It is hoped that with the concept of a sustainable road drainage model, this will be able to overcome runoff and can absorb water into the soil that is around the roads, so that water does not run off to other areas. Moreover, the existence of an aggregate filter in the channel can improve the quality of water that seeps into the soil.

\section{Acknowledgements}

Thanks to Educational Fund Management Institution (LPDP) Ministry of Finance of the Republic of Indonesia through the Indonesian Domestic Lecturers Excellent Scholarship Program (Budi-DN) in 2016.

\section{REFERENCES}

[1] Abi Aad, M. P., Suidan, M. T., \& Shuster, W. D. (2010). Modeling techniques of best management practices: Rain barrels and rain gardens using EPA SWMM-5. Journal of Hydrologic Engineering, 15(6), 434-443. https://doi.org/10.1061/(ASCE)HE.1943-5584.0000136

[2] Bisht, D. S., Chatterjee, C., Kalakoti, S., Upadhyay, P., Sahoo, M., \& Panda, A. (2016). Modeling urban floods and drainage using SWMM and MIKE URBAN: A case study. Natural Hazards, 84(2), 749-776. https://doi.org/10.1007/s11069-016-2455-1

[3] Carbone, M., Brunetti, G., \& Piro, P. (2014). Hydrological Performance of a Permeable Pavement in Mediterranean Climate. (June).

https://doi.org/10.5593/SGEM2014/B31/S12.050

[4] Golio, M. (2001). SUDS For Roads. Engineering, 20001220, 1347. https://doi.org/10.1201/9781420036763

[5] Guo, J. C. Y. (2009). Preservation Of Watershed Regime For Low Impact Development. Hydrologic Engineering, (January), 1-8.

[6] Guo, R., \& Guo, Y. (2018). Analytical Equations for Use in the Planning of Infiltration Facilities. Journal of Sustainable Water in the Built Environment, 4(2), 1-10. https://doi.org/10.1061/JSWBAY.0000849.

[7] Hein, D. K., Swan, D. ., \& Schaus, L. (2010). Structural and Hydrological Design of Permeable Pavement. Conference of The Transportation Association of Canada.

[8] Hendratta, L. A. (2014). Optimalisasi Sistem Jaringan Drainase Jalan Raya Sebagai Alternatif Penanganan Masalah Genangan Air. Tekno Sipil, 12(61), 9-24.

[9] Kanso, T., Tedoldi, D., Gromaire, M. C., Ramier, D., Saad, M., \& Chebbo, G. (2018). Horizontal and vertical variability of soil hydraulic properties in roadside sustainable drainage systems (SuDS)-nature and implications for hydrological performance evaluation. Water (Switzerland), 10(8). https://doi.org/10.3390/w1008 0987

[10] Miguez, M. G., Bahiense, J. M., Rezende, O. M., \& Veról, A. P. (2012). New urban developments: flood control and LID - a sustainable approach for urban drainage systems. 155, 469-480. https://doi.org/10.2495/SC120391

[11] Miguez, M. G., Bahiense, J. M., Rezende, O. M., \& Veról, A. P. (2014). Sustainable urban drainage approach, focusing on lid techniques, applied to the design of new housing subdivisions in the context of a growing city. International Journal of Sustainable Development and Planning, 9(4), 538-552. https://doi.org/10.2495/SDP-V9N4-538-552

[12] Mrowiec, M. (2016). Road Runoff Management Using Improved Infiltration Ponds. Transportation Research Procedia, 14, 2659-2667. https://doi.org/10.1016/j.trpro.20 16.05.435

[13] Owuama, C. O. (2014). Sustainable Drainage System for Road Networking. International Journal of Innovation, Management and Technology, 5(2). https://doi.org/10.776 3/ijimt.2014.v5.491

[14] Parkinson, J., \& Mark, O. (2005). Urban Stormwater Management in Developing Countries (p. 240). p. 240.

[15] Rizzo, A., Bresciani, R., Masi, F., Boano, F., Revelli, R., \& Ridolfi, L. (2018). Flood reduction as an ecosystem service of constructed wetlands for combined sewer overflow. Journal of Hydrology, 560, 150-159. https://doi.org/10.1016/j.jhydrol.2018.03.020

[16] Rossman, L. A. (2010). Storm Water Management Model User's Manual Version 5.0. 
[17] Rudiono, J. (2018). Priority Scale of Drainage Rehabilitation of Cilacap City. IOP Conference Series: Materials Science and Engineering, 333(1). https://doi.org/10.1088/1757-899X/333/1/012111

[18] Smith, D. R. (2006). Permeable Interlocking Concrete Pavement.

[19] Wang, J., Forman, B. A., \& Davis, A. P. (2018). Probabilistic stormwater runoffand water quality modeling of a highway in suburban Maryland. Journal of Hydrologic Engineering, 23(2), 1-12.

https://doi.org/10.1061/(ASCE)HE.1943-5584.0001600
[20] Yunianta, A., Suripin, \& Setiadji, B. H. (2018) Sustainable Road Drainage System : Experimental Model. Matec Web of Conferences.

[21] Yunianta, A., Suripin, \& Setiadji, B. H. (2019). Design of Sustainable Road Drainage System Model. Journal of Sustainable Engineering: Proceedings Series1(1), 35-45. https://doi.org/10.35793/jseps.v1i1.5

[22] Zhou, Q. (2014). A Review of Sustainable Urban Drainage Systems Considering the Climate Change and Urbanization Impacts. Water, 6(4), 976-992. https://doi.org/10.3390/w6040976 